\title{
El Gobierno de la República en el exilio. Crónica de un imposible retorno
}

\author{
XAVIER FLORES *
}

\section{RESUMEN}

El triunfo de los aliados en la Segunda Guerra Mundial hizo que los republicanos españoles exiliados en 1939 concibiesen esperanzas de un inmediato retorno de la República a su país con el apoyo aliado. Con esta idea se reconstituyeron las instituciones de la República Española en el exilio en México D. F., en agosto de 1945.

En este artículo se analiza el proceso de esa reconstitución y los

sucesivos gobiernos que se sucedieron hasta la disolución de las instituciones en junio de 1977 , después de un imposible retorno.

Palabras claves: República, exilio, instituciones, gobierno, reconstitución, retorno.

\begin{abstract}
The victory of the allies in the Second World war did that the Spanish republicans exiled in 1939 were conceiving hopes of an immediate return of the Republic to his(its) country with the allied support. With this idea there were re-constituted the institutions of the Spanish Republic in the exile in Mexico D.F., in August, 1945. In this article there are analyzed the process of this reconstitution and the successive governments that happened up to the dissolution of the institutions in June, 1977, after impossible I come back.
\end{abstract}

Key words: Republic, exile, institutions, government, reconstitution, return.

Aunque sólo sea para que la memoria no muera, no podemos olvidar la larga epopeya de las Instituciones republicanas en el exilio. Ahora que están de moda los llamados «hechos diferenciales" podemos destacarla

* Doctor en Letras y Ciencias Humanas por la Universidad de La Sorbona (Paris). Durante veinticinco años ha sido funcionario internacional al servicio de distintos organismos (ONU, UNESCO, OIT...). Ex-delegado diplomático del Gobierno de la República Española en el exilio. 
como un hecho único en la historia contemporánea. No guarda relación con los minigobiernos instalados en Londres durante la segunda guerra mundial, ni con las emigraciones italianas o alemanas de los años veinte y treinta, o de los rusos que escaparon a la revolución soviética. Nunca se dio el caso de un exilio tan numeroso con sus instituciones completas: Presidencia de la República, Gobierno, Cortes, partidos políticos, sindicatos, representación de las autonomías -Gobierno vasco y Generalidad de Cataluña-, asociaciones de todo tipo, etc., que se mantuvieron durante los cuatro decenios de la dictadura franquista como una media España frente a la otra media sojuzgada.

En 1976, cuando se discutía mezquinamente el alcance de la «Amnistía", anuncié en un largo artículo publicado el 14 de noviembre en El País "Los fantasmas de la dictadura» que el exilio no podría volver a España. Quedaban entonces, según datos del Office Français de Protection aux Réfugiés (OFPRA) unos 40.000 refugiados en Francia. En 1979, según la misma fuente, 15.951. En su gran mayoría, la diáspora española estaba en los cementerios de Europa y América. Los sobrevivientes -aquellos jóvenes de veinte años en 1936- eran ya abuelos sexagenarios con descendientes franceses, establecidos con recursos modestos y para quienes rehacer una vida en España era un sueño imposible. De las grandes figuras políticas sólo quedaba poco más de media docena de ancianos: Tarradellas, Carrillo, Dolores Ibarruri, Victoria Kent, Sánchez Albornoz, Maldonado, Madariaga, Llopis, Valera y alguno más. Los más importantes, Martínez Barrio, Álvaro de Albornoz, Jiménez de Asúa, Negrín, Giral, Gordón Ordás, Aguirre, Álvarez del Vayo, sin olvidar el primero que fue Azaña, habian fallecido ya. A la muerte de Franco, el exilio ya era un desierto político, aunque con los pocos dirigentes que quedaban en las Instituciones y en los partidos se había mantenido la lucha hasta la desaparición del dictador. Si por el tiempo pasado el retorno colectivo se habia vuelto imposible, la presencia misma del exilio con su capacidad de movilización de la opinión pública y de los partidos políticos, tanto en Francia como en otros países, logró algo significativo en nuestra historia: la reclusión del dictador que no se atrevió nunca a moverse de España a sabiendas del repudio que tendría que afrontar. Ningún gobernante le invitó nunca a visitar su país. Lo condenamos así a permanecer en la Península, inmerso en su visión fantástica del mundo. A imposible retorno, imposible salida.

Por todo ello, muchos creemos indispensable conocer la evolución de las Instituciones en el exilio para completar lo que fue la historia de nuestro país a lo largo de cuatro decenios de opresión. 


\section{LA CONTINUACIÓN DE LA RESISTENCIA}

Como primer antecedente del restablecimiento de las Instituciones republicanas en el exilio hemos de mencionar la Junta Española de la Liberación (J. E. L.), presidida por Diego Martínez Barrio, creada en México el 25 de noviembre de 1943. Fué ésta una vasta alianza de partidos (salvo el PNV, el PCE y la CNT por su carácter apolítico) que iba a desembocar, como veremos más adelante, en la primera reunión de las Cortes en el exilio celebrada en México el 10 de enero de 1945. Entretanto, los republicanos españoles habían recibido el primer aviso de insolidaridad por boca de Winston Churchill en la Cámara de los Comunes, el 14 de mayo de 1944. Creyéndose obligado a agradecer la no beligerancia de Franco y no haber bloqueado Gibraltar, Churchill no vaciló en afirmar que con ello había prestado un gran servicio al Reino Unido y a la causa de las Naciones Unidas y acabó manifestando que los problemas de política interior de España sólo concernían a los españoles y que al Reino Unido no le correspondía intervenir en ellos.

Con esta declaración empezó la larga pugna -que habría de durar hasta la muerte de Franco- entre la razón de Estado y la opinión pública de los países democráticos.

La primera sesión del Congreso español de los diputados se celebró el 10 de enero de 1945 en México con la asistencia de 72 diputados y la adhesión de 49 radicados en otros países. En vísperas de celebrarse una segunda sesión, los socialistas se opusieron con escrúpulos legales acerca de la existencia del quórum necesario, y también Indalecio Prieto que ya se había manifestado en La Habana en 1942 a favor de un plebiscito y no creia oportuno resucitar las Cortes en el exilio. Más adelante volveremos sobre la teoría plebiscitaria del líder socialista. Las sesiones se interrumpieron, pues, momentáneamente, dejando paso a las actividades de la Junta Española de Liberación.

\section{LA CONFERENCIA DE SAN FRANCISCO Y LA CUESTIÓN ESPAÑOLA}

Con motivo de la celebración de la Conferencia de San Francisco el 25 de abril de 1945 para preparar la Carta de las Naciones Unidas, la Junta Española de Liberación elaboró un extenso y minucioso memorándum sobre los orígenes y el desarrollo del régimen franquista. Como recuerda José María del Valle en su excelente obra sobre Las Instituciones 
de la República en exilio ${ }^{1}$, «sin más armas que las ediciones francesa, inglesa y española de este formidable documento, llegaron a San Francisco Álvaro de Albornoz, Félix Gordón Ordás, Antonio M. Sbert e Indalecio Prieto".

A pesar de la actitud negativa o abstencionista de las delegaciones norteamericana y británica, los cuatro enviados desplegaron una gran labor de captación entre las delegaciones hispanoamericanas y europeas (sobre todo Francia, Bélgica, Checoslovaquia, Yugoslavia y la URSS, que expresaron su adhesión).

Indalecio Prieto manifestó públicamente cómo podría restablecerse la República Española en cuatro etapas: I. ${ }^{9}$ Repudia del régimen de Franco por la Conferencia de San Francisco; 2.9 Ruptura de las relaciones diplomáticas; 3. Formación de un gobierno provisional nombrado por las Cortes; $4 .^{9}$ Reconocimiento de este gobierno por las Naciones Unidas 2.

Pero antes de superar esta etapa había que resolver el problema del doctor Juan Negrín, presidente todavía del Gobierno republicano, que había acudido a San Francisco. Se entrevistaron con él Gordón Ordás y Álvarez del Vayo. Gordón Ordás, siempre minucioso en sus escritos nos dejó notas de la conversación con Negrín de las que se desprende que sólo dimitiría ante el Presidente provisional de la República, elegido en una reunión de las Cortes. Para ello, habría de acudir a México a fin de dar cuenta de su gobierno, de sus ideas y de sus propósitos.

Mientras, en San Francisco se discutía el proyecto de Dumbarton Oaks para el establecimiento de una organización internacional, uno de cuyos puntos afirmaba que «el organismo estará abierto a todos los países amantes de la paz", lo que le permitiría a Franco hacer alardes de pacifismo y colarse de rondón en las futuras Naciones Unidas.

Los delegados de la J.E.L. lograron que la delegación de México apoyara una enmienda formulada por ellos y precisada por el francés Georges Bidault a fin de que sólo pudieran incorporarse los países «cuyo régimen no se hubiese establecido con la cooperación militar de Estados que combatieron a las Naciones Unidas". El embajador mexicano Quintanilla defendió esta enmienda el 19 de junio en un conmovedor discurso sobre los antecedentes del franquismo, subrayando que sería «irónico

1 Editada por Ruedo Ibérico, París 1976.

2 España, México, 9 de junio de 1945, y J. M. DEL VALLE, op. cit. pág. 106. 
que la derrota de Hitler y Mussolini afirme la posición de Franco en el mundo de la posguerra".

Acogida con indescriptible entusiasmo, la enmienda fue aceptada por aclamación sin ningún voto en contra. Justo es recordar con eterno agradecimiento que los españoles lograron este éxito gracias al apoyo personal del presidente Ávila Camacho a quien se lo pidió Félix Gordón Ordás: "Váyase tranquilo, señor embajador -le contestó- y asegúreles a sus compañeros de mi parte que el proyecto de ustedes, para el cual les deseo el éxito que merece, será apoyado íntegramente por la delegación de México, que considerará un honor poder prestar su voz oficial donde no puede resonar la de ustedes ${ }^{3}$.

\section{CONSECUENCIAS DE LA CONFERENCIA DE SAN FRANCISCO}

La razón de Estado, mantenida principalmente por el gobierno británico, tuvo una influencia negativa en el desarrollo de los acontecimientos. Cierto es que en la reunión celebrada a fines de julio de 1945 en Potsdam, Roosevelt, Churchill y Stalin condenaron tajantemente en su declaración al gobierno español, rechazando de antemano toda solicitud de ingreso, dados sus orígenes, su establecimiento con ayuda de las potencias del Eje, y su carencia de las calificacionés necesarias para justificar su admisión entre las Naciones Unidas 4.

Esta declaración y la resolución de San Francisco fueron revalidadas por la primera Asamblea General de la ONU celebrada en Londres en febrero de 1946: "La Asamblea General, al hacer suyas estas dos declaraciones, recomienda a los miembros de las Naciones Unidas que actúen de acuerdo con la letra y el espíritu de esas declaraciones en sus relaciones futuras con Espana».

Era un paso importante, pero no decisivo. Además de negarle la entrada a España en el club de Naciones Unidas ¿qué podían hacer éstas para eliminar al dictador? La respuesta, que tendría prolongadas y negativas consecuencias, llegó el 4 de marzo de 1946 con la llamada Nota Tripartita de Francia, el Reino Unido y Estados Unidos de América, que suponía reanudar la política del Comité de no Intervención adoptada en 1936:

3 Félix Gordón Ordás, Mi política fuera de España, México D. F., 1967, t. II, pág. 730.

4 Véase un resumen del debate en Florentino Portero, Franco Aislado, Madrid, Aguilar, 1989, pág. 79 y ss. 
«Los gobiernos de Francia, del Reino Unido y de los Estados Unidos han procedido a un cambio de opiniones concerniente al gobierno actual de España y sus relaciones con ese régimen. Han reconocido que en tanto el general Franco continúe gobernando en España el pueblo español no podrá contar con una colaboración cordial y completa con las naciones del mundo que, por su común esfuerzo, han provocado la derrota del nazismo alemán y del fascismo italiano, que han ayudado al régimen español actual a acceder al poder, y sobre los cuales este régimen ha tomado modelo.

No entra en las intenciones de estos tres gobiernos intervenir en los asuntos internos de España. El pueblo español debe, a fin de cuentas, fijar su propio destino. A despecho de las medidas represivas tomadas por el régimen actual contra los esfuerzos ordenados del pueblo español para expresar y dar forma a sus aspiraciones políticas, los tres gobiernos esperan que el pueblo español no conocerá de nuevo los horrores y las amargas experiencias de la guerra civil.

Desean, al contrario, que unos dirigentes españoles, patriotas y liberales consigan provocar la retirada pacífica de Franco, la abolición de Falange y el establecimiento de un gobierno provisional o encargado de la expedición de los asuntos corrientes, bajo cuya autoridad el pueblo español tuviera la posibilidad de determinar libremente el tipo de gobierno y de elegir sus representantes ${ }^{5}$."

Esta nota tripartita no era más, en suma, que la mera expresión de buenos deseos para España, pero sin compromiso alguno de ayudar eficazmente al restablecimiento de la democracia. El gobierno británico, preocupado con la evolución en los Balcanes y complicado en el embrollo griego, temía que un nuevo frente abierto en España alterase su política de estabilidad en el Mediterráneo. Contando además con la amistad de Portugal, era mejor que la Península lbérica no se conmoviese demasiado y se mantuviera neutral y, en palabras de Churchill, como "poderoso factor de paz". Intuyendo el futuro de Europa, al día siguiente de la declaración tripartita, Churchill, en el Westrninster College de Fulton, ante Truman, pronunció su veredicto: «Desde Stettin, en el Báltico, a Trieste en el Adriático, un telón de acero se ha abatido sobre Europa».

A pesar de esta política de contención, más que de intervención, los firmantes de la Nota Tripartita no pudieron evitar que en la Asamblea General de Naciones Unidas, reunida poco después en octubre de 1946, el secretario general Trygve Lie, bajo la presión de un gran número de delegaciones, manifestara el deseo de que se incorporase el tema de España al orden del día de la Asamblea (no estaba previsto por depender todavía

5 Cf. el texto comploto, del que sólo reproducimos lo esencial, en J. M. DEL VALLE, op. cit., págs. 155-156. 
del Consejo de Seguridad) y que ésta prestara «el gran servicio de dar unas directivas bien definidas a los organismos y a los Estados miembros de las Naciones Unidas en lo que respecta a sus relaciones con el régimen de Franco.»

En el largo debate sobre la cuestión española quedó claramente definida la posición de los partidarios de una ruptura diplomática y comercial, y la de los opuestos a tal toma de medidas. El senador Connally, delegado de los Estados Unidos, manifestó claramente que pertenecía al pueblo español «decidir la naturaleza de su gobierno» y que el general Franco tenía que entregar sus poderes a un gobierno representativo del pueblo español que respetara las libertades, convocara unas elecciones para que la nación, libre de coacciones, expresara su voluntad. En la misma línea se pronunció el delegado del Reino Unido, radicalmente opuesto a toda ruptura de relaciones diplomáticas y comerciales y convencido además de que si el pueblo español era verdaderamente entusiasta de la democracia y la libertad, acabaría por encontrar su propia salvación ${ }^{6}$. Frente a esta postura, envuelta en consideraciones sobre el peligro de una nueva guerra civil, no pesaron mucho los argumentos de las delegaciones partidarias de una ruptura de las relaciones diplomáticas e incluso comerciales (URSS, Francia, México y Polonia, entre otras) pero al final se impuso una solución intermedia: la retirada de embajadores, con la advertencia de que si en "plazo razonable» (cuya duración no precisa la resolución) no se habia producido un cambio democrático en España, el Consejo de Seguridad habría de estudiar las medidas adecuadas a tomar para remediar esta situación. Además, la Asamblea recomendaba a los Estados miembros que dieran cuenta al Secretario General y a la próxima Asamblea de las medidas adoptadas a estos efectos.

Pasó un año. En la siguiente Asamblea General -noviembre de 1947se reiteró su confianza en que el Consejo de Seguridad «ejercerá sus funciones conforme a la Carta en cuanto considere que así lo exige la situación de España». Meses más tarde, en junio de 1948, el Consejo de Seguridad tropezó con la negativa de los Estados Unidos de ejercer ninguna acción, y la afirmación del delegado argentino de que la cuestión española era un asunto interno del pueblo español en el que el Consejo de Seguridad no tiene ninguna jurisdicción. La posición contraria, representada por la URSS y Ucrania, no tuvo éxito y, en vista de que las posiciones eran radicalmente opuestas, los ocho delegados restantes decidieron abstenerse, quedando asi aplazada la cuestión española en la ONU.

6 J.M. DEL VALE, Op. cit., págs. 217 y ss. 
Ya en plena guerra fría, en mayo de 1949, la Asamblea General de la ONU, habida cuenta de que «en la resolución de 1946 no se habla prescrito la ruptura de relaciones políticas y comerciales con el Gobierno de España" decidió «sin desaprobar las declaraciones que figuran en la resolución de 12 de diciembre de 1946, dejar a los Estados Miembros con entera libertad de acción en lo relativo a sus relaciones diplomáticas con España 7".

Así, aun "no desaprobando las declaraciones" para taparse las vergüenzas, los autores de la resolución -Brasil, Bolivia, Colombia y Perúdejaron el camino abierto a la definitiva reconciliación con el régimen franquista, dejando en el aire a toda la oposición.

Ante la evidencia de que el problema español había pasado a un segundo plano para los Aliados, ocupados en los distintos frentes de la guerra fría y necesitados de mantener por razones geoestratégicas la estabilidad de la Península Ibérica garantizada por Salazar y Franco, la Asamblea de las Naciones Unidas volvió a tratar la cuestión española en su quinta sesión y aprobó el 4 de noviembre de 1950 una resolución en virtud de la cual se revocaba la recomendación de retiro de embajadores y ministros plenipotenciarios aprobada el 12 de diciembre de 1946, así como la aprobada en la misma fecha con objeto de que se impidiera que España fuera miembro de los organismos internacionales establecidos por las Naciones Unidas o vinculados con ésta 8 .

Aún pasarían cinco años hasta que el régimen franquista ingresase en la ONU el 14 de diciembre de 1955.

\section{ORIGGENES Y EVOLUCIÓN DEL GOBIERNO REPUBLICANO EN EL EXILIO}

En estas circunstancias ¿qué podía hacer el Gobierno de la República en el exilio? Poco para derrocar a Franco, mucho para tenerlo aislado de la opinión pública internacional y para mantener la mala conciencia de los gobiernos atentos sólo a los dictados de la Razón de Estado.

Entretanto, las Instituciones en el exilio no habian permanecido inertes. Forzoso es recapitular su evolución desde sus orígenes para comprender su permanencia hasta la muerte de Franco, pues es la historia de

7 Cf. Gordón ORDÁs, op. cit., t. II, pág. 757.

( Ídem, pág. 760. 
media España frente a la otra media. De hecho, hasta la constitución del gobierno Giral no tuvimos realmente un gobierno en el exilio. El gobierno Negrín, nombrado en mayo de 1937, seguía manteniendo su legitimidad fuera de España. En las reuniones celebradas en París a fines de marzo de 1939 ante la Diputación Permanente de las Cortes, Negrín opuso sus reservas a la legitimidad y autenticidad de la representación parlamentaria allí presente, cuyas facultades para pedirle cuentas ponía en tela de juicio. Martínez Barrio, presidente de la Diputación, y Álvaro de Albornoz, sumamente contrariados, objetaron que el gobierno Negrín, situado fuera de España, había dejado de existir. Después de un largo debate sobre las competencias de ambos organismos se llegó a una solución transaccional manifestando: 1.9 que la Diputación Permanente, en función de su derecho, examina una actuación del gobierno; $2 .^{9}$ que cree, después de las manifestaciones del señor Negrín, que el gobierno representado por el señor Negrín no puede dejar de serlo por imposibilidad de declinar su cargo ante el órgano constitucional adecuado; $3 .^{\circ}$ que no existiendo el órgano constitucional adecuado para aceptar la dimisión del gobierno del señor Negrín, que se designe una comisión de seis miembros que, con su presidente, mantenga contacto permanente con el gobierno, fiscalice su gestión y asegure la compenetración entre éste y los partidos afectos a la República ${ }^{9}$. En suma, como lo expresó Ramón Lamoneda, no había ni dimisión de gobierno ni una sucesión de gobierno.

Liquidado así el pleito legitimista, dominado por escrúpulos jurídicos característicos de la mentalidad de los dirigentes exiliados, el gobierno Negrín asumió la representación de la legalidad republicana formando lo que podemos llamar un Frente Común (más adelante volveremos sobre esta expresión) según se aprecia por su composición ministerial:

Presidencia y Defensa: Dr. Juan Negrín

Estado: Julio Álvarez del Vayo (socialista)

Hacienda: Francisco Méndez Aspe (Izquierda Republicana)

Gobernación: Paulino Gómez (socialista)

Justicia: Ramón González Peña (socialista)

Obras Públicas: Antonio Velao (Izquierda Republicana)

Comunicaciones: Bernardo Giner de los Ríos (Unión Republicana)

Agricultura: Vicente Uribe (comunista)

Trabajo: José Moix (PSUC)

Ministros sin cartera: Tomas Bilbao (Acción Nacionalista Vasca) y José Giral (Izquierda Republicana)

9 J. M. del VAlle, op. cit., págs. 30-31. 
Además de mantener la presencia de la causa republicana en el exterior el gobierno Negrín prosiguió la tarea fundamental iniciada en 1937 en colaboración con el gobierno francés: la evacuación, ayuda y asentamiento de los refugiados, a través del Servicio de Emigración de los Republicanos Españoles (SERE) creado en marzo de 1939. El reconocimiento de Franco dificultó pronto la gestión del SERE como organismo autónomo. Para evitar las posibles reclamaciones de las autoridades de Burgos, el gobierno republicano, de acuerdo con el gobierno francés y la Legación de México, puso al SERE bajo la tutela del gobierno mexicano. Gracias a esto, los representantes del SERE, provistos de un «laissez-passer» especial y de una autorización de la Legación de México, pudieron proseguir su labor de ayuda a los refugiados y censar a aquellos que deseaban emigrar a México ${ }^{10}$.

Paralelamente al SERE se constituyó en julio de 1939 la Junta de Auxilio a los Republicanos Españoles (JARE) gracias a los fondos obtenidos con el cargamento del yate EI Vita. La historia es harto conocida y ha sido relatada minuciosamente por José María del Valle y otros autores. Después de varias peripecias con la Administración mexicana en Veracruz, con ciento y pico de maletas de alhajas y objetos de valor incautados en las cajas de los bancos, Indalecio Prieto logró del general Cárdenas la franquicia diplomática y el depósito, bajo su custodia, del cargamento. Poco más tarde, Prieto intentó, con el acuerdo de la JARE recién creada, devolver el cargamento de EI Vita al gobierno de Burgos a cambio de que Franco autorizase el regreso, sin represalias, de la mayoría de los exiliados, salvo unos miles que, por razón de los cargos desempeñados, juzgara Franco inaceptables.

Esta gestión la hizo personalmente Prieto con el embajador José Félix de Lequerica. Éste, partidario de tal solución humanitaria, la trasladó a Burgos donde Franco la rechazó. Demostró entonces una vez más que no le importaba la suerte de cientos de miles de compatriotas.

Finalmente, la JARE quedó integrada en 1942 en una Financiera Hispano-Americana, para ajustarse a la legislación mexicana, y a través de este organismo prosiguió su labor de ayuda a los refugiados promo-

10 Después de la firma del Pacto germario-soviético, el SERE fue disuelto por el gobierno francés, quedando la Junta de Auxilio a los Republicanos Españoles (JARE) como único organismo responsable de la emigración. Ct. Geneviève DreYfus-Armand, L'exil des republicains espagnols en France, París, Albin Michel, 1999, págs. 79-80. No conocemos las cuentas del SERE. Según Negrín se disponia de unos 250 millones de francos situados previamente a la derrota en el extranjero. Cf. DEL VALLE, op. cit., págs. 33-34. 
viendo multitud de empresas económicas y culturales que tuvieron un enorme y positivo impacto en el desarrollo del país.

El 1 de diciembre de 1943, el gobierno mexicano, aparentemente no satisfecho de las actividades políticas derivadas del funcionamiento de la JARE, decidió incautar sus bienes creando una Comisión Administrativa de los fondos de auxilio a los republicanos españoles (CAFARE). Los españoles no habian respetado suficientemente el Acuerdo presidencial de 21 de enero de 1941 que les imponía el deber de abstenerse de actuaciones políticas. Por otra parte, la JARE no podía seguir como órgano representativo de un poder extranjero, argumento que ponia en tela de juicio la persistencia del gobierno Negrín.

\section{LA JUNTA ESPAÑOLA DE LIBERACIÓN Y EL RESTABLECIMIENTO DE LAS INSTITUCIONES EN MÉXICO}

Para hacer frente a la provisionalidad de las Instituciones en el exilio, la Unión de Profesores Universitarios Emigrados, por iniciativa del doctor Gustavo Pittaluga, refugiado en Cuba, decidió promover una serie de acuerdos - llamados la Declaración de la Habana 11_ el 22 de octubre de 1943 en la capital de Cuba.

Esta declaración, transmitida por José Giral a las personalidades políticas más destacadas -Martínez Barrio, Albornoz, Prieto y Negrín, entre otros- motivó una serie de reuniones en México que concluyeron con la firma, el 20 de noviembre de 1943, de un pacto de unidad para restablecer la República Española. A este pacto se sumó la mayoría de los partidos que habían votado la Constitución de 1931, salvo, ya entonces, el PNV que ponia en duda los preceptos de la Constitución y la realidad de la unidad de España, así como el Partido Comunista invocando la oposición de una Junta Suprema de Liberación Nacional que se habría formado en España.

Como hemos mencionado al principio, la J.E.L. tuvo una gran influencia en la Conferencia de San Francisco gracias a la mediación y apoyo de México. Pero el acontecimiento principal impulsado por la J.E.L., la Diputación Permanente de las Cortes y el propio Martínez Barrio, fue la reunión de las Cortes en México para el restablecimiento definitivo de las Instituciones: Presidencia de la República, Cortes y Gobierno.

11 Cf. el texto de la Declaración en J. M. DEL VALLE, op. cit., págs. 73-74. 
Restablecer el orden con el fin de obtener el máximo reconocimiento internacional era la preocupación primordial de Martínez Barrio. Tropezó al principio con la oposición del gobierno mexicano a que se reunieran las Cortes exiliadas en la capital, pero al final logró del general Ávila Camacho su aquiescencia pasiva y la concesión de extraterritorialidad para una reunión de Cortes en el "Club France» el 10 de enero de 1945.

Como lo hemos señalado al principio, la reunión se celebró pero no pasó de la primera sesión a causa de la minoría socialista, so pretexto de que no existía quórum y era mejor transformar las Cortes en una mera junta de diputados para «llegar a soluciones políticas exentas de carácter parlamentario ${ }^{12}$ ». No cabe duda de que Prieto, hostil a la actuación de las Cortes y partidario ya de una solución plebiscitaria, era el inspirador de la actitud de la minoría socialista. Habiendo pedido los socialistas la suspensión de las sesiones, Martínez Barrio cedió pero sin cerrar el ciclo parlamentario.

Sortear los obstáculos puestos por unos y por otros no era, pues, cosa fácil. Poco después del éxito obtenido en San Francisco, el exilio no podía quedarse a la espera, sine die, de su reorganización.

El 5 de agosto de 1945, recién regresado a México, el doctor Negrín, todavía jefe del gobierno en el exilio, pronunció un extenso discurso en el teatro del Palacio de Bellas Artes ante más de seis mil exiliados y miembros del cuerpo diplomático acreditados en México.

En su discurso el doctor Negrín expresó claramente por qué se había negado hasta entonces a dimitir, pensando que las responsabilidades políticas debían exigirse en España ante las Cortes y con el control de la opinión pública, No obstante, dado el tiempo transcurrido, estaba dispuesto a resignar su mandato ante el Parlamento reunido, después de un acuerdo previo de los partidos, y una vez resuelta la provisión de la vacante de la presidencia de la República.

Cumpliendo con los requisitos planteados por Negrín se reunieron los representantes de los partidos y, después de haber superado algunos obstáculos formales de una fracción del PSOE que seguía dividida, se convino por unanimidad pedir al presidente de las Cortes, Martínez Barrio, que convocase al Congreso de los diputados con la mayor urgencia a fin de asumir ante éste la presidencia de la República.

12 ldem, pág. 88. 
El Congreso se reunió el 17 de agosto en el salón de Cabildos del Palacio del Gobierno de la ciudad de México, con la autorización y las inmunidades concedidas por el gobierno. Acudieron a la ceremonia 96 diputados y numerosas representaciones diplomáticas y altos cargos del gobierno mexicano. Martínez Barrio prestó juramento de fidelidad a la República y quedó nombrado Presidente interino de la República.

El doctor Negrín presentó el mismo día una carta de dimisión de su gobierno y Martínez Barrio inició las consultas reglamentarias con los partidos. Las minorías parlamentarias reunidas se centraron en dos candidatos posibles para presidir el Gobierno: el doctor Negrín y el doctor Giral, de Izquierda Republicana, quien fue finalmente elegido por gran mayoría. Martínez Barrio confió acto seguido a Giral la misión de formar un gobierno representativo de todos los partidos y fuerzas sociales defensores de la Constitución.

\section{EL GOBIERNO GIRAL}

La tarea encomendada no era nada fácil. Por una parte, Félix Gordón Ordás, presidente de Unión Republicana, había advertido a Martínez Barrio y a Giral, partidarios ambos de no hacer exclusiones, que no aceptaría incorporarse al gobierno representando a Unión Republicana si participaban en él los comunistas: "Jamás aceptaré figurar con el Partido Comunista -declaró Gordón a Martínez Barrio- en ningún gobierno ordinario, ni en el exilio, ni en España ${ }^{13}$. Años más tarde, como veremos, mantendría inflexible esta conducta frente a los que propugnaban -entre ellos el autor de estas lineas- un frente común antifranquista.

Por otra parte, Giral había de tropezar con otros obstáculos. Al entablar sus consultas ofreció la vicepresidencia y la cartera de Estado a $\mathrm{Ne}$ grín que éste rechazó so pretexto de que su agrupación política se oponía a ello porque el nuevo gobierno no entrañaría la continuación de su política. También los comunistas se negaron a colaborar con un gobierno que no estuviese presidido por Negrín.

Así quedó despejado el camino, si no de un gobierno de concentración, si de uno con mayoría en el Parlamento. Giral se enfrentó todavía con la negativa de Indalecio Prieto y de José Tarradellas (Esquerra Republicana de Cataluña).

13 Gordón Ordas, op. cit., t. II, pág. 782. 
Al cabo de un mes de gestiones, Giral presentó la lista de su gobierno lamentando que algunos sectores se quedaran fuera, pero dejándoles la puerta abierta «porque todos son necesarios, aunque nadie es imprescindible en la tarea de la recuperación de la República."

El gobierno quedó constituido con los siguientes ministros: Presidencia: Giral (Izquierda Republicana); Estado: Fernando de los Ríos (PSOE); Hacienda: Augusto Barcia (IR); Justicia: Álvaro de Albornoz (IR); Defensa: general Hernández Sarabia (sin partido); Gobernación: Manuel Torres Campaná (Unión Republicana); Instrucción Pública: Miguel Santaló (Esquerra); Navegación, Industria y Comercio: Manuel Irujo (PNV); Emigración: Trifón Gómez (UGT); Ministros sin cartera: Angel Osorio y Gallardo (sin partido) y Luis Nicolau d'Olwer (Acció Republicana Catalana) ${ }^{14}$. Esta lista fue ampliada después con dos ministros de la CNT: Horacio Martínez Prieto (Obras Públicas) y José E. Leiva (Agricultura).

Una vez constituido el gobierno y comunicada su lista al secretario de Relaciones Exteriores de México, Manuel Tello, ésie acusó recibo comunicando el pleno reconocimiento de México a la legitimidad del gobierno republicano, que había de mantener hasta la muerte de Franco ${ }^{15}$.

Seguidamente, otros países reconocieron la legitimidad del gobierno: Guatemala y Panamá fueron los primeros. A fines de marzo de 1946, el gobierno de Polonia, el 5 de abril, el de Rumania, seguido por Venezuela, Checoslovaquia y Hungría, y algo más tarde Yugoslavia, cuya fidelidad se mantendría también hasta el final del franquismo. La embajada de España en México quedó al servicio del gobierno republicano. En total, nueve gobiernos reconocieron entonces al de la República en el exilio. Faltaron, como era de esperar, los gobiernos de las cuatro grandes potencias vencedoras: Estados Unidos, Inglaterra, Francia y Rusia, las tres primeras por los motivos ya expuestos, y Rusia porque no le convenia alterar la división acordada en Yalta.

Las Cortes se reunieron en el Salón de Cabildos los días 7, 8 y 9 de noviembre ratificando su adhesión al gobierno, pero Indalecio Prieto, en una larga declaración la condicionó, el día 8, al éxito que pudiera tener su gestión:

«Si al gobierno le acompaña $\epsilon l$ éxito, nada tendremos que decir (...) Pero si el éxito no corona el sacrificio de esos gobernantes alineados ante nosotros

14 Gordón ORdÁs, op. cit., t. II, pág. 783.

15 Cf. Gaceta Oficial de la Republica Española, 7 de septiembre de 1945. 
¿podremos entonces contemplar tranquilamente la pérdida de lozanía y de vitalidad, la pérdida de energía de los órganos constitucionales, en resumen, su propia sequedad o su asfixia?

«(...) El apoyo más entusiasta será el nuestro en el presente; mas no comprometemos el futuro ante instituciones que no tienen plazo alguno para su cese (...) pero digo al Gobierno y al Congreso, recogiendo el voto de la Minoria Socialista, expresado unánimemente, que si, habiendo perdido vitalidad dichas instituciones, surgiera en el campo internacional o en el nacional otra solución digna para restaurar la República y España la aceptase, nosotros la serviremos 16."

Con esta declaración Prieto dejaba traslucir su preferencia por un plebiscito, ya expresada en La Habana en 1942. No esperó mucho tiempo para reiterarla, el 7 de diciembre de 1945 en una conferencia dedicada a la Juventud Socialista sobre el tema: «¿Cómo podría verificarse un plebiscito en España?". La idea de un plebiscito tardaría diez años en imponerse a todos, pero con unas condiciones muy precisas como veremos más adelante, aceptadas por todos y especialmente por los socialistas. La idea de Prieto en 1942 era organizar un plebiscito dirigido y controlado por las naciones americanas de habla española, sueño que venía madurando, según él, desde 1938 17. En los años cincuenta enfocaríamos esa hipótesis con más sensatez, aunque no con más eficacia.

El gobierno Giral, ya en funciones, aprovechó el éxito obtenido en la Conferencia de San Francisco para proseguir sus gestiones diplomáticas y asegurar su posición internacional. Para ello necesitaba trasladarse a París, por su proximidad con España y para fortalecer sus relaciones con los gobiernos y partidos democráticos europeos.

El 15 de enero de 1946, con el apoyo casi unánime de los diputados, la Asamblea Nacional francesa «felicita al gobierno francés por la iniciativa que ha tomado de dirigir una nota proponiendo a los gobiernos de Gran Bretaña y de los Estados Unidos romper las relaciones diplomáticas con el gobierno de Franco ${ }^{18}$."

16 Gordón OrdÁs, op. cit., t. II, págs. 802-803.

17 Indalecio Prieto, Convulsiones de España, Discursos en América, Barcelona, Editorial Planeta 1991, t. I, pág. 156.

18 Bulletin de Presse Espagnole, 15, 14 de febrero de 1946. 
Entretanto, había llegado de México el dia 8 el presidente Giral que fue recibido por seis de sus ministros que ya se hallaban en París. El día 11, el gobierno francés concedió el visado de entrada al presidente Martínez Barrio que se embarcó el 16 en Nueva York, rumbo al Havre. El 9 de febrero fue el turno de José Antonio de Aguirre, presidente del gobierno vasco. Reunidos Giral, Aguirre y José Irla, presidente de la Generalidad, lanzaron el día 22 la siguiente declaración:

"1. Afirmamos nuestra fe en la República como única solución democrática, justa y libre de los problemas diversos y complicados que se plantean hoy al pueblo cuyos intereses representamos legítimamente.

2.9 Proclamamos nuestra decisión de liquidar, en una atmósfera de generosidad, la guerra civil, $y$ de fundar, en una amplia base de colaboración, las tareas que se nos imponen.

3. Sólo la República puede dar satisfacción a las numerosas víctimas del francofalangismo, que durante tantos años ha sometido al pueblo a toda clase de vejaciones y de crimenes materiales y espirituales, individuales y colectivos. Los abajo firmantes manifiestan su voluntad de conducir esta labor con rapidez y con todas las garantías jurídicas que el franquismo ha rehusado a sus víctimas.

4..$^{2}$ El gobierno de la República y los gobiernos autónomos cuentan con la adhesión de la Resistencia y de los pueblos que ellos representan.

5. ${ }^{2}$ La atmósfera internacional, cada vez más favorable, y las corrientes históricas facilitarán las realizaciones gubernamentales y la liberación de los pueblos peninsulares.

6. ${ }^{2}$ Somos clara y legítimamente republicanos y no admitimos ninguna clase de compromisos ni de colaboración con quien sea. A la dictadura franquista debe suceder, inmediatamente y sin etapas intermedias, la restauración de la República.

7. La consulta al pueblo español se realizará lo más rápidamente posible, una vez restablecido el régimen republicano. Lo prometemos formalmente ${ }^{19}$."

Franco acogió esta nota con total indiferencia. En el interior, los conatos de oposición de una Alianza Nacional de Fuerzas Democráticas, compuesta de personalidades republicanas, socialistas, cenetistas y de otros partidos, además de la colaboración del general Aranda, habían sido rápidamente desmontados y Aranda pasado a la reserva 20.

19 J. M. DEL VAUE, op. cit., pág. 152. 
Los monárquicos corrieron la misma suerte por haber mandado a don Juan de Borbón un manifiesto de adhesión a su llegada a Lisboa. Kindelán fue desterrado a Canarias y fueron sancionados, entre otros, el duque de Maura, Melchor Fernández Almagro y el duque de Alba. Los gobiernos democráticos observaron con calma estas actuaciones del dictador hasta que un hecho cruento colmó su paciencia. Un grupo de diez guerrilleros encabezado por Cristino García, héroe de la Resistencia francesa, había sido detenido y sus miembros condenados a muerte. A pesar de la petición del gobierno francés de medidas de clemencia, el 22 de febrero de 1946 se publicó su ejecución. Cuatro días más tarde, el gobierno francés, movido por la presión de la Asamblea Nacional, decretó el cierre de la frontera a partir del 1 de marzo de 1946. Franco, impasible, la cerró un día antes y Francia la volvió a abrir a principios de febrero de 1948.

Dada la gravedad de ésta decisión, hubiera sido lógico que la apoyaran los ingleses y los norteamericanos. El gobierno americano optó por una posición abstencionista y propuso a los de París y Londres hacer una declaración común, la famosa Nota Tripartita del 4 de marzo, ya reproducida más arriba, que dejaba al pueblo español resolver sólo y a su libre albedrío la salida de la dictadura.

El gobierno Giral contestó a esta nota con una declaración subrayando que «si la España civil del interior no se ha desembarazado aún de Franco y de Falange, no es porque esperaba la declaración de las tres grandes potencias, sino por la imposibilidad absoluta en la que se encuentra, por hallarse oprimida y desarmada ${ }^{21}$."

Algo más que lanzar protestas en vano tenía que hacer el gobierno Giral. Aprovechando la llegada a París del presidente Martínez Barrio, el 12 de marzo, Giral, respaldado plenamente por él, declaró públicamente su propósito de ampliar el gobierno. Pese a las objeciones de Prieto y venciendo el temor de que una incorporación de los comunistas al gobierno influyese negativamente en los Aliados, se constituyó el segundo gobierno, después del de Negrín, que puede calificarse de frente común. Ya no

20 Sobre la evolución de la ANFD, véase Xavier TUSELL, La oposición democrática al franquismo, Barcelona, Planeta, 1977, págs. 153-161, y Alicia ALTED VIGIL, La oposición republicana 1939-1977, en Nigel Townson (ed), El republicanismo en España (1830-1977), Madrid, Alianza, 1994, págs. 233-235. J. M. DEL VALLE también traza la evolución de la ANFD y revela el dato curioso de que Juan March quiso financiarla. Cf. op. cit., págs. 136-141.

21 La Nouvelle Espagne, 15 de marzo de 1946. 
podrían esgrimirse como pretexto las divergencias de los exiliados, pese a la permanencia de pequeños grupos críticos que nunca faltan en esas ocasiones.

Con esta ampliación entraron los comunistas representados por Santiago Carrillo, los galleguistas con Alfonso Rodríguez Castelao, liberal centrista, y la derecha republicana con Rafael Sánchez Guerra. ¿Qué más personalidades patriotas podian desear los autores de la Nota Tripartita para promover un cambio en España?

A pesar del abstencionismo de la Nota Tripartita, el gobierno polaco de Unión Nacional reconoció oficialmente al gobierno español en el exilio el 5 de abril de 1946. También Rumania, entonces monarquía constitucional, rompió sus relaciones con el gobierno franquista. Polonia fue más lejos anunciando en el Consejo de Seguridad de la ONU que pediría que la cuestión española se mantuviera en su orden del día. La declaración de su embajador en París muestra hasta qué punto el tema de España era sensible para un país martirizado por los nazis y cuya capital había quedado reducida a un campo de escombros:

«El gobierno de Polonia ha decidido plantear el caso español porque tiene la opinión de que la existencia del régimen fascista del general Franco amenaza la paz. Las resoluciones de Potsdam decidían liquidar los restos del fascismo que constituyen un peligro para la paz. En este orden de ideas la proposición polaca es la consecuencia de las decisiones antifascistas de la reunión de Potsdam. El derecho moral de intervenir en la cuestión española le pertenece a Polonia por el hecho de que miles de polacos han participado en la defensa de la democracia española (...) Polonia, que ha perdido cinco millones de ciudadanos en el combate contra el fascismo, tiene derecho a tomar la iniciativa de liquidar el último refugio del fascismo en Europa (...) Franco ofrece el derecho de asilo a todos los elementos fascistas (...) Es también una amenaza evidente para la paz. En Polonia, tanto los hombres de Estado como el pueblo entero se alegran y se enorgullecen de que ei gobierno polaco haya tomado la iniciativa de liquidar el último vestigio del fascismo en Europa 22».

Ante el Consejo de Seguridad, en la sesión del 11 de abril de 1946,Oscar Lange, delegado de Polonia, pidió la ruptura de las relaciones diplomáticas con el gobierno franquista, con el apoyo de Henri Bounet, delegado de Francia, y de Castillo Nájera, delegado de México. El debate se dividió entre partidarios de la ruptura -Gromiko, por la URSS, recordó el fracaso de la no intervención - y partidarios de la abstención. Finalmente, se convino en crear un subsomité encargado de estudiar la situación española. 
El subcomité, que había requerido la ayuda de todos los paises que pudieran proporcionarle información complementaria, recibió un abrumador memorándum del gobierno republicano. En Londres, Giral afirmó ante la prensa que, en cuanto se restableciera la legalidad republicana, en España se celebrarían elecciones libres y, si el pueblo votara a favor de la Monarquía, se aceptaría su voluntad soberana. Giral fue invitado dos veces por el subcomité a ampliar verbalmente su memorándum.

El subcomité, después de un minucioso examen de la situación, llegó a la conclusión de que el Consejo de Seguridad debía asumir los principios de la Nota Tripartita y al mismo tiempo recomendar a la Asamblea General que, en caso de que no se cumplieran las condiciones enunciadas en dicha nota, votara una resolución recomendando que cada miembro de las Naciones Unidas rompiera inmediatamente las relaciones diplomáticas con el régimen franquista. Finalmente, después de largos debates, se dejó la cuestión pendiente hasta el mes de septiembre en que pasaría a estudio de la Asamblea General.

El 23 de octubre de 1946 se reunió la Asamblea General de Naciones Unidas. El 12 de diciembre se aprobó finalmente por mayoría la retirada de embajadores, cuya resolución ya reprodujimos extractada.

Giral había logrado un gran éxito, aunque no totalmente satisfactorio, pues la Asamblea General carece de poder ejecutivo, al contrario del Consejo de Seguridad.

Al regresar a París le esperaba una desagradable sorpresa. Indalecio Prieto, descontento con la resolución aprobada por la Asamblea General, había pronunciado en México el 17 de diciembre un discurso muy crítico de la política de Giral, declarándose partidario de un acercamiento a todas las fuerzas opositoras, incluidos los monárquicos. Para ello preconizaba la retirada de los socialistas del gobierno Giral.

Reaccionó Giral ante su gabinete el 22 de enero de 1947, proponiendo toda clase de medidas: creación de un consejo de la resistencia en el interior, ampliación del gobierno con representantes de otras fuerzas antifranquistas, etc. Pero, al acabar su exposición, Sánchez Guerra manifestó que Giral había agotado ya todas sus posibilidades y no era el hombre adecuado para una nueva política. Su dimisión acarreó la de Trifón Gómez (UGT), Enrique de Francisco (PSOE), Martínez Prieto y Leiva (CNT).

En vista de ello, Giral presentó su dimisión al presidente Martínez Barrio. A juicio de los ministros socialistas, el gobierno Giral había perdido 
autoridad entre los exiliados, no había obtenido la confianza de las fuerzas del interior de España y no había logrado en la atmósfera internacional la colaboración que esperaba. Por su parte, los ministros de la CNT preconizaron la formación de un nuevo gobierno en estrecho contacto con la Alianza Nacional de Fuerzas Democráticas ${ }^{23}$.

Martínez Barrio, después de haber intentado que formase gobierno Augusto Barcia Trelles, que fracasó en sus gestiones tachado de demasiado identificado con la política de Giral, decidió confiar el encargo a Rodolfo Llopis, que lo aceptó el 9 de febrero de 1947.

\section{EL GOBIERNO LLOPIS}

El nuevo gobierno, organizado sobre la base de un acercamiento con las fuerzas del interior, la continuidad de una política internacional de acuerdo con la actitud adoptada por la ONU el 12 de diciembre anterior, y con la afirmación de que el gobierno debería ser el organismo que dirigiera la consulta al país sobre la elección del régimen futuro, se compuso con los miembros siguientes: Presidencia y Estado: Llopis, Justicia: Irujo (PNV); Hacienda: Valera (UR); Defensa: Just (IR); Instrucción Pública: Santaló (Izquierda Catalana); Emigración: Trifón Gómez (UGT); Economia: Vicente Uribe (PCE); Información: Luis Montoliú (CNT).

Este gobierno, más flexible que el de Giral, conjugaba la permanencia de las Instituciones republicanas con la posibilidad de un gobierno provisional representativo de todas las formas de opinión, mediante el acercamiento a las fuerzas que luchaban en el interior de España. Pero, para esto hacia falta que, siguiendo la orientación de Prieto, se lograse celebrar un plebiscito o una consulta electoral en España. El 8 de marzo, en un artículo titulado «O plebiscito o monarquia» decía Prieto claramente:

"Conviene examinar como se realizaría el plebiscito o la consulta electoral. Dos formas son posibles, una estrictamente plebiscitaria por medio de la cual el pueblo diría de manera directa que régimen político prefiere; la otra, que serfa sencillamente una consulta electoral de carácter constitucional, en la que el pueblo daría a conocer su opinión por medio de candidatos elegidos $24 . n$.

23 Cf. L'Espagne Republicaine, 25 de enero 1947, y España Libre, 1 de febrero de 1947.

24 L'Espagne Republicaine, 8 de marzo de 1947. 
A esta propuesta respondió la fracción negrinista, partidaria del establecimiento puro y simple de la República y adversaria de todo plebiscito o consulta electoral. Lanzaron su manifiesto anunciando la creación de la «España combatiente» para reforzar la resistencia interior, estableciendo estrechos contactos y prestando toda la colaboración posible. Justificaba su postura el temor de que Llopis, en connivencia con el gobierno británico, favoreciera el acceso al trono de don Juan de Borbón.

Es cierto que en Estoril pululaban entonces personalidades republicanas, socialistas y sindicales, discutiendo cuál sería la mejor fórmula para liquidar a Franco: monarquía previa seguida de elecciones, o plebiscito asegurado por un gobierno neutro, ni republicano ni monárquico.

Todo esto era puro sueño; sin medios económicos, sin fuerzas reales dentro de España y sin la voluntad de los Aliados de abandonar su política de no intervención, poco podía hacerse. Se especulaba con la oposición de algunos generales - Aranda, Beigbeder, Kindelán y algunos másque Franco tenia perfectamente controlados. Los republicanos, reducidos a tertulias nostálgicas o encarcelados en cuanto se movían, las guerrillas en el campo, perseguidas y eliminadas poco a poco por la guardia civil, no constituian un grave problema de orden público. Dicho sea sin menospreciar la actuación de los socialistas y, sobre todo de los comunistas, que muchas veces la pagaron con su vida. Sin esperanza fundada en algo sólido y no en meras declaraciones de los Aliados, era inevitable que en el exilio se magnificara la resistencia interior.

Para apuntalar su régimen, Franco lanzó el 1 de abril de 1947 la Ley de Sucesión que convertía su magistratura en vitalicia y la monarquía en electiva. Don Juan de Borbón reaccionó con un manifiesto durísimo tachando de nula la ley que vulneraba los principios que rigen la sucesión a la Corona 25 . Con la Ley de Sucesión, Franco le cerraba el paso al príncipe que le había ofrecido la Regencia en octubre de $1941^{26}$. Pero Franco tenía otro plan que desvelaría más tarde y le llevaría a gobernar hasta la muerte.

El gobierno republicano reiteró su defensa del origen legal de la República y su oposición «por todos los medios a que otro régimen se instale de manera arbitraria 27». Llopis continuó con su programa de unión de todos los antifranquistas -incluida la Unión Nacional de Fuerzas Democráticas- con el apoyo eventual de los gobiernos aliados. Esta polí-

25 Luis Maria ANSÓN, Don Juan, Madrid, 1994, pág. 264.

26 Pedro Sainz Rodriguez, Un reinado en la sombra, Barcelona, Planeta, 1981, págs. 350-351.

27 Boletín de Información, 14 de abril de 1947. 
tica estaba destinada al fracaso. En el interior, la Alianza estaba en crisis con diferencias insalvables entre socialistas, comunistas y cenetistas en cuanto a una política de entendimiento con los monárquicos. Con las fuerzas armadas no había nada que hacer. Salvo media docena de generales, los demás, aunque se declarasen monárquicos, eran ante todo franquistas y después monárquicos en la medida en que la monarquia garantizase la continuidad del orden establecido. Franco se aseguró el éxito sometiendo el 6 de julio a referéndum la Ley de Sucesión con un resultado a su favor de 93 por ciento. No hubo ningún movimiento en contra y don Juan tardaría años en convencerse de su trágica soledad.

Al gobierno Llopis le quedaba poca vida. Sus gestiones no habían dado el resultado apetecido. EI Congreso del PSOE se inició en Toulouse el 25 de julio de 1947 con la asistencia de Indalecio Prieto. Llopis expuso el cambio operado desde el legalismo de Giral a la "constitución de un gobierno que se asemejase lo más posible a aquél de que hablaba la nota tripartita $28_{\text {\%. }}$ ¡Sublime ingenuidad! ¿No habían comprendido acaso los socialistas que la Nota Tripartita era la prolongación de la política de no intervención en la guerra civil? ¿Habían olvidado que Ernest Bevin, secretario del Foreign Office, en su primer discurso en la Cámara de los Comunes, el 20 de agosto de 1945, habia declarado tajantemente que «la cuestión del régimen de España es algo que le corresponde decidir al pueblo español"?

Indalecio Prieto llegó al Congreso con la idea fija de cambiar la política del gobierno y excluir a los comunistas, considerando que con su permanencia «las potencias occidentales, a pesar de todas sus declaraciones públicas u oficiosas, no darán jamás su aprobación a un régimen en el que ellas vean un peligro de predominancia comunista 29 ». Además, acusó a Llopis de no haber respetado las resoluciones adoptadas por el partido en 1946 prohibiendo la participación comunista.

Llopis le contestó que la participación comunista había sido requerida y apoyada por Izquierda Republicana, Unión Republicana, Esquerra Catalana y los nacionalistas vascos. Añadió algo de suma importancia respecto de la participación comunista, manifestando que cuando las resoluciones de 1946 fueron comunicadas a los socialistas del interior éstos respondieron: "La resolución adoptada por vuestro Congreso de Toulouse sobre las relaciones con el Partido Comunista ha sorprendido y desconcertado a la masa de nuestros miembros y ha descontentado francamente a la mayor parte 
de entre ellos. En España es imposible seguiros en esa actitud. Sería inoportuno y políticamente injusto para nosotros adoptar una resolución semejante a la vuestra". Para los residentes en España, conocedores de los sacrificios asumidos por los comunistas y de la cantidad de condenados a largas penas de cárcel, la actitud de Prieto era efectivamente inadmisible ${ }^{30}$.

En aquel Congreso Prieto logró, sin embargo, que se aprobase una resolución reiterando la decisión adoptada en mayo de 1946 respecto al Partido Comunista. Además, propuso la creación de un instrumento gubernamental provisional que respondiera a los deseos expresados por las Naciones Unidas en la Nota Tripartita.

Para ello, hacia falta que desapareciese el gobierno republicano. Prieto había declarado ya el 6 de febrero ante la Minoría Socialista que las Cortes eran lo único que debía subsistir de las Instituciones republicanas. Trifón Gómez, con buen sentido, se opuso a las tesis de Prieto sosteniendo que el gobierno era el único instrumento de trabajo con que podía el partido mantener su posición. Pero, al adoptar el punto de vista de Prieto, el Congreso provocó la crisis del gobierno Llopis. El 5 de agosto de 1947, Vicente Uribe, representante del PCE, presentó su dimisión, y al día siguiente presentaba Llopis al presidente de la República la dimisión de su gobierno. Había durado sólo seis meses.

Con la dimisión de Llopis se acabaron los gobiernos de concentración nacional 0 , mejor dicho, de frente común antifranquista.

\section{EL GOBIERNO ALBORNOZ}

Martínez Barrio, en su búsqueda de un nuevo gobierno, tropezó con el rechazo de vascos y catalanes si no participaban también los socialistas. En vista de ello confió el 15 de agosto a Álvaro de Albornoz la misión de formar un gobierno con representantes de los partidos republicanos nacionales exclusivamente. El nuevo gobierno quedó así constituido: Presidencia y Relaciones Exteriores: Albornoz (IR); Justicia y Hacienda: Valera (UR); Gobernación: Just (IR); Defensa: general Hernández Sarabia (sin partido); Emigración: Torres Campaná (UR); Instrucción Pública e Información: Sal-

30 Véase el resumen de este debate en Carlos y José MARTínez COBos, ¿República? ¿Monarquia? En busca de consenso. Intrahistoria del PSOE, vol. II (1946-1954), Barcelona, Plaza y Janés, 1992, págs. 132-141, y J. M. DEL VALLE, op. cit., págs. 253-259. 
vador Quemades (IR); Economía: Eugenio Arauz (Partido Federal). En este gobierno figuraba como subsecretario de la presidencia José Maldonado que, años más tarde, sería el último presidente de la República.

Con su escasa representatividad, el gobierno Albornoz fue desarrollando lo mejor posible su actuación. Podemos decir que a partir de entonces la política del exilio se mueve alrededor de un triángulo: la legitimidad republicana, la legitimidad monárquica y la reivindicación plebiscitaria de Prieto.

Álvaro de Albornoz se presentó en Nueva York para recabar el apoyo de las delegaciones afines al gobierno republicano en la Asamblea de la ONU. Entre el 10 y el 12 de noviembre de 1947 la Primera Comisión (temas políticos y de seguridad) dedicó largas sesiones a la resolución que la Asamblea General debería adoptar sobre España. El delegado polaco Oscar Lange propuso que la Asamblea recomendara al Consejo de Seguridad que, en el plazo de un mes, examinara la situación con miras a aplicar las medidas previstas en el artículo 41 de la Carta: interrupción total o parcial de relaciones económicas y comunicaciones, así como la ruptura de relaciones diplomáticas.

Esta propuesta, tan sólo aprobada por las delegaciones de los países del Este, fue desechada por los demás países. Finalmente, después de largas discusiones, la Asamblea General, como ya lo señalamos, se limitó a reiterar su confianza en que el Consejo de Seguridad ejercería sus funciones cuando así lo exigiera la situación de España. Esta resolución, adoptada el 17 de noviembre, significaba un éxito para el régimen franquista, pero no un fracaso total para los republicanos, pues la resolución del 12 de diciembre de 1946 no quedaba anulada, si bien la devolución del tema al Consejo de Seguridad suspendía, sine die, toda actuación positiva en la cuestión española.

Albornoz volvió con la cabeza gacha, disimulando su desencanto en unas declaraciones destinadas como siempre a reforzar la política y las fuerzas republicanas del interior y del exterior. Izquierda Republicana del interior lanzó una soflama acusando a los gobiernos anglosajones de querer restablecer la monarquía y ser responsables del mantenimiento de Franco, lo cual provocó una dura contestación de Esquerra Catalana preguntando con quién entonces iba a proseguir su política el gobierno Albornoz: ¿Con los países del Este?

Estábamos, pues, en plena confusión. Entretanto, el 10 de enero de 1948, Francia que había cerrado la frontera en 1946 la volvió a abrir, ya 
que ningún otro país la había seguido en la interrupción de relaciones comerciales.

El golpe era duro, aunque sin mayores consecuencias para la estabilidad del gobierno republicano. Albornoz multiplicó sus visitas a las repúblicas hispanoamericanas amigas, pero sin resultados tangibles. Prieto, por su lado, expuso sus puntos de vista al Foreign Office y logró que en el Congreso Socialista celebrado en marzo le reiteraran su confianza -así como a Jiménez de Asúa, Trifón Gómez y Antonio Pérez-para que continuara sus negociaciones con los monárquicos. Hasta entonces no habían dado resultado alguno. En una conversación anterior en Londres con Gil Robles había quedado claro que los monárquicos no aceptarian ningún gobierno provisional de coalición y menos aún un plebiscito, como quería Prieto, sobre el régimen futuro de España.

A pesar de estos obstáculos, socialistas y monárquicos llegaron a un acuerdo el 30 de agosto de 1948, el llamado Pacto de San Juan de Luz ${ }^{31}$. Precedido de una serie de consideraciones sobre la amnistía o el orden público, el libre ejercicio del culto, etc., que reflejaban los deseos unánimes de toda la oposición, el pacto terminaba con una declaración importante para los socialistas:

«Previa devolución de las libertades ciudadanas, que se efectuará con el ritmo más rápido que las circunstancias permitan, consultar a la Nación a fin de establecer, bien en forma directa o a través de representantes, pero en cualquier caso mediante voto secreto, al que tendrán derecho todos los españoles de ambos sexos, capacitados para emitirlo, un régimen político definitivo. El Gobierno que presida esta consulta deberá ser, por su composición y por la significación de sus miembros, eficaz garantía de imparcialidad».

La propuesta de establecer por voto secreto el establecimiento de un régimen político definitivo coincidia con la teoría plebiscitaria de Prieto, que la mantuvo hasta su muerte. Pero no era aceptable para don Juan, quien, el 13 de abril de 1946, habia declarado en The Observer: «Encarno una Institución que tiene sus raíces en la Historia y en la misma contextura de la sociedad española. Por consecuencia, el principio de legitimidad que esa Institución significa, no puede depender, en mi sentir, de la voluntad de una mayoría transitoria ${ }^{32}$."

31 Cf. José Maria Gll Robles, La monarquía por la que yo luché, Madrid, 1976, págs. $410-$ 411. Este acuerdo, negociado por Félix Vejarano, de acuerdo con Pedro Sainz Rodríguez y Gil Robles, fue firmado por Indalecio Prieto y el conde de los Andes en San Juan de Luz.

32 Ansón, op. cit., pág. 267. 
Huelga decir que este pacto de 1948 no tuvo ninguna eficacia. En aquellas fechas se habia iniciado, el 24 de junio de 1948, el bloqueo soviético de Berlín que obligó a los Aliados a establecer un gigantesco puente aéreo para llevar suministros a dos millones y medio de personas de la zona occidental. El 4 de abril de 1949 las potencias aliadas firmaron el Pacto del Atlántico (OTAN) y los soviéticos, ante su fracaso, pusieron fin al bloqueo el 12 de mayo siguiente. Es evidente que en ese momento de alta tensión de la guerra fría, los gobiernos firmantes de la Nota Tripartita a la que se agarraba Prieto como última esperanza, no tenian el menor propósito de alterar el statu quo en España.

Álvaro de Albornoz impugnó la validez del acuerdo de San Juan de Luz por no ser representativo más que de una ínfima minoría de los monárquicos y no llevar además la firma del Pretendiente o, en su defecto, de un representante suyo debidamente autorizado. Era pedirle peras al olmo. Don Juan mantuvo siempre la postura de que el rey no podía negociar con partidos políticos. Además, la firma del acuerdo habría significado agravar su discrepancia con Franco cuando ya había decidido confiarle la educación del príncipe Juan Carlos.

Decepcionado por la falta de resultados positivos en Nueva York, Álvaro de Albornoz presentó su dimisión a Martínez Barrio, quien, después de evacuadas las consultas, confió de nuevo a Albornoz, el 6 de diciembre de 1948, la constitución de un gobierno más apto para el despliegue institucional. El nuevo gobierno, constituido el 16 de febrero de 1949, quedó así compuesto: Presidencia y Estado: Albornoz (IR); vicepresidente y Hacienda: Valera (UR); Justicia: Maldonado (IR); ministro sin cartera y secretario del Consejo: Arauz (PRF); ministros sin cartera con misión en América: Gordón Ordás, general Asensio y Vicente Sol Sánchez; ministros sin cartera con misión en Europa: Manuel Serra Moret y José Maria de Semprún y Gurrea.

Quedaban así suprimidas Defensa, Emigración, Instrucción Publica e Información y Economia, que en el anterior gobierno reflejaban más lo que podía ser un gobierno en España que uno de resistencia en la emigración.

Al reanudarse el tercer periodo de sesiones de la Asamblea General en abril de 1949, volvió a plantearse el problema español y, como hemos señalando al principio, se decidió dar libertad de acción a los países miembros en sus relaciones diplomáticas con España 33.

33 Véase sobre las largas negociaciones que motivó esta resolución, Florentino PORTERo, op. cit., págs. 318-338. 
De momento, esto no supuso la vuelta de un tropel de embajadores. En los Estados Unidos, Truman y Dean Acheson, secretario de Estado, se oponían frente al Pentágono a designar un embajador en España, por cuanto podría considerarse un reconocimiento del régimen de Franco e iba en contra de la resolución de 1946 que no había sido expresamente anulada. En suma, mantener relaciones económicas sin ir más allá, en espera de lo que decidiera la próxima Asamblea General de la ONU. Esta era la situación a principios de 1950.

En el Foreign Office, Bevin era partidario de mantener el statu quo en la ONU, frente a la oposición de los conservadores en el Parlamento, encabezada por el propio Churchill. Había creído en 1949 en las posibilidades de un acuerdo monárquico-socialista impulsado por Prieto, y en una acción conjunta con americanos y franceses ante el general Aranda, pero éste habia sido pasado a la reserva por Franco y la idea de un gobierno militar de transición carecía de sentido.

La situación creada por la guerra de Corea contribuyó a que poco a poco se atenuara el debate entre los partidarios del aislamiento y sus contrarios en el bloque occidental. A pesar de la oposición del Kremlin se optó finalmente por incluir la cuestión española en la quinta sesión de la Asamblea General de Naciones Unidas en septiembre de 1950. Siete países latinoamericanos -Bolivia, Costa Rica, República Dominicana, El Salvador, Honduras, Nicaragua y Perú- a los que se sumó Filipinas, presentaron un proyecto de resolución favorable al intercambio de relaciones diplomáticas y al ingreso del gobierno español en los organismos especializados de la ONU, anulándose así lo dispuesto en la recomendación de 1946. El proyecto de resolución fue aprobado el 4 de noviembre por 37 votos a favor, 10 en contra y 12 abstenciones.

Esta decisión representaba un claro retroceso para el gobierno Albornoz y un modesto triunfo para Franco, pues no implicaba su ingreso en la ONU, que tardaría años en producirse.

El gobierno republicano reaccionó el 9 de noviembre lanzando en términos patéticos un largo mensaje firmado por el presidente Martínez Barrio y todos los ministros del gobierno:

“... El voto de la Asamblea de las Naciones Unidas está ahí, como un reto a la conciencia democrática y un sarcástico comentario a la ideologia tan distante como escarnecida de las democracias en lucha contra el nazi- 
fascismo. Si Hitler y Mussolini no hubieran sucumbido en uno de esos momentos en que la victoria actúa como una némesis vengadora, serian, a fuerza de anticomunistas acérrimos, dos candidatos al aerópago de «los grandes", y los ahorcados de Nuremberg se dispondrían a trocar la hopa infamante por el dorado uniforme de embajadores. Para eso hubo millones de muertos y el mundo se vio envuelto en la catástrofe que supera en horror la guerra de los «Treinta Años". Para eso cayeron en Noruega, en África, y en Italia, y en Francia y en Alemania, millares de españoles republicanos, supervivientes de la llamada "guerra civil», que dieron su vida por la victoria de las naciones aliadas. $Y$ los valientes antifranquistas que entraron en $\mathrm{Pa}$ rís con Leclerc, y vivieron en el Hotel de Ville uno de los instantes más gloriosos de su existencia, son hoy unos "sin patria", proscriptos y errabundos a través de la tierra ${ }^{34}$."

En el PSOE, Rodolfo Llopis se sumó a esta denuncia destacando el hecho revelador del cambio político de los gobiernos de que "ni un solo pais de Europa dirigido por los socialistas ha votado contra Franco ${ }^{35}$." Indalecio Prieto, profundamente desanimado, dimitió desde San Juan de Luz el 6 de noviembre, de la representación del partido en el Comité de Enlace con los monárquicos, y al mismo tiempo de la presidencia del partido con estas palabras:

«Mi fracaso es completo. Soy responsable de haber inducido a nuestro partido a fiarse de poderosos gobiernos democráticos que no merecian esta confianza, como acaban de demostrarlo. Por mi culpa, mi partido ha sido víctima de una ilusión que ha deslumbrado. ¿Dónde va a conducirme ahora mi desilusión? No lo sé. Lo que sé es que los actos que yo pueda hacer y las palabras que pueda decir a este respecto tendrían una resonancia oficial si continuara ocupando, aunque sólo sea de nombre, la presidencia del Partido. Por ello dimito $36 . "$

La crisis del PSOE también se extendió al gobierno republicano. Estimando que la resolución de la ONU obstruía el camino emprendido por la oposición democrática, Álvaro de Albornoz presentó el 30 de noviembre su dimisión al presidente Martínez Barrio. Este le ratificó en vano su confianza, y Albornoz continuó a la cabeza del gobierno hasta el 8 de julio de 1951 en que presentó su dimisión definitiva.

34 Véase el mensaje completo en Gordón ORDás, op. cit., págs. 761-763.

35 Euzko Deya, París, 22 de noviembre de 1950.

36 El Socialista, 16 de noviembre de 1950, y J. M. DEL VALLE, op. cit., págs. 316-317. 


\section{EL GOBIERNO GORDÓN ORDÁS}

Encargado por Martínez Barrio, el 13 de agosto de 1951, de formar gobierno, Félix Gordón Ordás se encontró en una situación difícil. Intentó sin éxito formar un gobierno de partidos -Izquierda Republicana se negó por estimar que seguiría la misma política de Albornoz- y al final tuvo que resignarse a constituir un gobierno de personalidades «libres de la disciplina de partidos». El gobierno quedó así compuesto: Presidencia y Hacienda: Gordón Ordás; Estado: Valera; Justicia: Puig y Ferreté; Ácción en el Interior y en el Exilio: Just; Información y Propaganda: Arauz; Asuntos militares: general Herrera; ministros consejeros: Roma, Semprún Gurrea; Londres, José Antonio Balbontín; Nueva York, Victoria Kent. Quedó finalmente constituido el gobierno el 17 de noviembre, y entretanto los ministros de Albornoz radicados en Francia siguieron asumiendo sus funciones.

En su declaración ministerial del 23 de noviembre, Gordón Ordás reiteró la voluntad del gobierno «de atenerse escrupulosamente al sostenimiento del principio de legitimidad de las Instituciones republicanas", tal como había sido ratificado por el Parlamento reunido en México en noviembre de 1945. Reivindicando el derecho de las Instituciones en el exilio a ser restauradas en España "como primera medida del retorno a la legalidad y a la normalidad", añadió Gordón, en clara alusión a Prieto, que «ni arriaremos la bandera de le legitimidad ni aceptaremos ningún proyecto de disolución en el destierro de las Instituciones

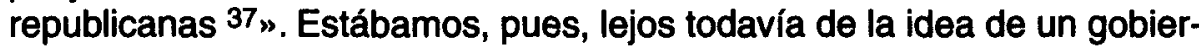
no sin signo institucional acompañado de un plebiscito previo, que surgiría en la segunda mitad de los años cincuenta.

Recordando la Carta de San Francisco pronunció Gordón Ordás unas frases que merecen recordarse porque, no sólo definen su visión del mundo, sino también porque ahora cobran una indudable actualidad:

«Nuestra política (...) ha de guardar siempre estrecha relación con los principios esenciales que norman la vida pública de Europa occidental (...) Jamás aprobaremos la doctrina del Estado-Dios, se patrocine por los tiranos de la derecha, del centro o de la izquierda. Pero igualmente que de los totalitarismos fascista y comunista, somos adversarios del totalitarismo supercapitalista, que aunque se disfrace con la máscara liberal y democrática es también esclavizador de pueblos y expoliador de derechos humanos. A esta actitud nos obligan nuestra adhesión sin reservas a la Carta de Derechos y Deberes promulgada

37 Gordón ORdÁs, op. cit., t. IV (I), págs. 69-73. 
en San Francisco de California y nuestra devoción por la doctrina jurídica que dio origen a la Sociedad de Naciones y hoy a las Naciones Unidas ${ }^{38}$."

Asi inició su periplo gubernamental Gordón Ordás. Podemos dividirlo en dos partes: la primera de 1951 a 1955 y la segunda de 1956 a 1960. Durante la primera parte, a pesar de sus numerosos desplazamientos a América Latina y a Yugoslavia invitado por el mariscal Tito en 1952, la suerte fue claramente desfavorable al gobierno republicano en el ámbito internacional. El 17 de noviembre de 1952 la España franquista ingresó en la UNESCO a pesar de las múltiples protestas de delegaciones amigas, organismos no gubernamentales, escritores, científicos, etc., que reflejaban la opinión pública francesa.

El 28 de agosto de 1953 le tocó el turno al Vaticano con un concordato suscrito por el ministro Martín Artajo y el embajador Castiella. Con ello, Pio XII, el Papa diplomático, lavaba los pecados del general Franco y lo convertía en persona grata para los católicos americanos. Pocos días después, el 26 de septiembre de 1953, el gobierno americano suscribía el Pacto de las Bases cuyo alcance huelga precisar.

Para afianzar aún más esta política, los Estados Unidos consiguieron que a España se le concediera un puesto de observador permanente en la ONU en enero de 1955. Sólo era un compás de espera. Entre los Estados Unidos y la Unión Soviética se organiza un verdadero cambalache diplomático en virtud del cual si los Estados Unidos no se oponen a los candidatos al ingreso en la ONU presentados por Rusia, ésta no se opondrá al ingreso del gobierno franquista. Concluido el acuerdo, y con el visto bueno del Consejo de Seguridad, la Asamblea General aprobó el ingreso de España el 14 de diciembre con sólo dos abstenciones: México y Bélgica.

Gordón Ordás, en una última batalla, envió un memorándum a todos los delegados de las Naciones Unidas y telegramas a los presidentes de los países amigos. Los partidos republicanos pidieron a Molotov que hiciera uso de su derecho de veto, pero todo fue en vano. España no era más que un peón en la guerra fría y la estabilidad de la península ibérica con sus dos dictadores -Franco y Salazar- una garantía geoestratégica para las potencias occidentales.

A pesar de la derrota el gobierno republicano mantuvo en su segunda etapa ${ }^{39}$ que se abría tras el ingreso de España en la ONU una intensa

38 idem, pág. 70.

39 En esta segunda etapa Gordón modificó ligeramente su gobierno: sustituyó a Arauz por Salvador Etcheverría, Julio Just asumió Justicia, habiendo cesado Puig y Ferreté, y siguieron 
actividad, esta vez más orientada hacia la acción clandestina en España y con largos viajes por América Latina y Estados Unidos, donde se logró neutralizar la tentación de incorporar España a la OTAN.

Consciente de que habían pasado muchos años desde la victoria de Franco y de que en España habían surgido nuevas generaciones, Gordón Ordás fue cambiando de posición respecto de la sustitución de Franco y, sin arriar la bandera de la legitimidad, recordó en su mensaje del 1 de enero de 1958 que «numerosas veces hemos dicho (...) en el memorándum que repartí en 1955 entre varios jefes de Estado, que estamos dispuestos a transigir con que el pleito español se resuelva mediante la formación de un gobierno provisional sin signo institucional previo, que haga una consulta electoral libre y garantizada con compromiso adquirido por todas las partes contendientes de respetar el resultado que se obtenga en homenaje a la soberanía nacional ${ }^{40 . "}$

Poco más podía hacer el gobierno en aquellas circunstancias. Dentro de España proliferaban los grupos de oposición y embriones de partidos (Gordón enumera unos treinta ${ }^{41}$ ). Un grupo reducido, encabezado por Enrique Tierno Galván, consiguió conmover a los dirigentes de las fuerzas exiliadas con el envío de un documento en el que les sometía tres hipótesis: a) que la forma de gobierno fuera elegida por el pueblo español; b) que la forma de gobierno que haya de suceder a la caída del régimen actual sea implantada sin previa consulta al país; a) que la forma de gobierno, aunque impuesta de facto seria posteriormente legitimada por la consulta al pais ${ }^{42}$."

Sobre estas tres hipótesis las fuerzas políticas contestaron apoyando la primera y reiterando la necesidad de una situación transitoria sin signo institucional definido, reflejo de la política ya adoptada por el gobierno republicano. Esto fue el llamado Pacto de París, suscrito por todas las fuerzas políticas, excluidos los comunistas: PSOE, Izquierda y Unión republicanas, Partido Federal, PNV, Acción Nacionalista Vasca, Esquerra Republicana Catalana, Moviment Socialista de Cataluña, UGT, CNT y Solidaridad de Trabajadores Vascos. El Pacto fue dado a conocer por el gobierno y los partidos en febrero de 1957.

como ministros consejeros los mismos, salvo Victoria Kent sustituida por el general Asensio en Nueva York.

40 Gordón ORDÁs, op. cit., t. IV (1) pág. 115.

41 lódem pág. 854.

42 Lealtad, mayo-junio 1957. 
Gordón Ordás continuó por su parte haciendo múltiples gestiones en América Latina y Estados Unidos y conquistando indudablemente la simpatía de la opinión pública, pero sin que se modificara la política de ningún gobierno. Franco había logrado penetrar en la ONU y en sus organismos especializados. Sólo le quedaban dos obstáculos insalvables: el ingreso en la Comunidad Europea y en la OTAN. A su ingreso en la OTAN, gracias a una gestión eficacísima de Gordón, el diputado Charles O. Porter se opuso en la Cámara de Representantes el 12 de mayo de 1959 con estas palabras:

«Nuestra política en España necesita una reconsideración cuidadosa y cambios drásticos. A menos que cambiemos nuestros métodos inmediatamente, el gobierno que siga será casi seguramente antiamericano. (...) Recientemente, un distinguido español exilado, el doctor Félix Gordón Ordás, presidente del Consejo de Ministros de la República Española en el exilio, vino a mi despacho y, a petición mía, preparó un informe presentando ciertos hechos sobre la situación actual en España. Después de obtener un consentimiento unánime, inserto una traducción de su informe a continuación de estas observaciones. Los hechos que él presenta enseñan que no debemos recomendar la admisión de España en la NATO; que debemos arreglar la forma de que nuestras estaciones de radio sean oídas por el pueblo español, que no nos debemos dejar engañar por el peligro del comunismo en España; $y$, finalmente, que debemos reexaminar la totalidad de nuestro programa de asistencia económica a España ${ }^{43}$."

En cuanto a la incorporación a la Comunidad Europea lo impedía el Tratado de Roma. A pesar de sus esfuerzos, Franco seguiría hasta su muerte aislado de estos dos centros neurálgicos fundamentales de la política europea.

El 18 de abril de 1960 -después de ocho largos años de gobiernoGordón Oidás presentó su dimisión irrevocable al presidente Martínez Barrio, a raíz de una imprudente y absurda intervención de éste en el banquete celebrado el día anterior para conmemorar, como cada año, el 14 de abril republicano. No sólo asistió el gobierno en pleno, sino también grupcs partidarios de la reconquista de España con guerrillas armadas, entre ellos una fantasmagórica "Unión de Combatientes Españoles" de un autodenominado general Bayo. Miembros de estos grupos hostiles a la política de no violencia del gobierno acudieron a escuchar el discurso de Martínez Barrio -único orador del banquete- que empezó moderadamen-

43 GoRdón ORDÁs, op. cit., IV (1), págs. 943-945, que contienen el memorándum de Gordón Ordás además de la declaración de Charles $\mathrm{O}$. Porter. 
te y acabó al final con un llamamiento a la juventud afirmando «que ella tenía el deber de ser violenta porque con la violencia hasta se puede obtener el reino de Dios $\mathbf{4 4}^{4}$

Con estas frases aplaudidas por los insensatos, hasta el punto de que uno llegó a gritar que le diesen un fusil, Martínez Barrio quebraba la política de no violencia mantenida desde 1945 por las Instituciones y los partidos políticos democráticos. Gordón Ordás, a la vista de esta declaración del presidente, se presentó al día siguiente en su casa y le comunicó su dimisión irrevocable y su regreso a México. La violencia, ni por alusiones, tal era el principio que había sostenido siempre este gran político. A él le debemos la política de apertura a las nuevas generaciones, la difusión de documentos importantes como el extraordinario "Testimonio de las generaciones ajenas a la guerra civil» procedente de la Agrupación Socialista Universitaria en 1957, y de cuantas informaciones nos remitían del interior. Esta apertura del gobierno a la juventud disidente se mantendría también en los gobiernos sucesivos.

Además de los documentos enviados desde el interior, se publicó también un informe, Monarquía o Repüblica, elaborado por el autor de estas líneas y firmado X.A.F. para no personalizarlo, en el cual se proponia la tesis de la libre elección de régimen, habida cuenta de la existencia de nuevas generaciones en España que no habían nacido durante la República ni tenían obligación de acatarla. Este documento, aceptado por Gordón Ordás, fue publicado por el gobierno republicano y por el gobierno vasco. Influyó sin duda en el acercamiento a las tesis del gobierno sin signo institucional, sin que ello menoscabara el principio de legitimidad de las Instituciones en el exilio 45.

Otro documento importante fue el remitido al Vaticano en 1957 por intermedio de José María Semprún y Gurrea, solicitando del Papa Pio XII su intercesión para que en los conventos, obispados y parroquias del pais se concediese el derecho de asilo a todos los católicos perseguidos por simples delitos de opinión. Esta petición, difundida por la prensa del exilio, no obtuvo respuesta, pese a que el Vaticano estaba al corriente de las detenciones operadas por el régimen en círculos católicos ${ }^{46}$. Otros muchos

44 Gordón Ordas, op. cit., IV (I), pág. 1.153.

45 Cf. España Republicana, Buenos Aires, 15 y 30 de octubre y 15 de noviembre de 1957; España Libre, Nueva York, 20 de septiembre de 1957, y Euzko Deya, Boletín del Gobierno Vasco, 6-11 de septiembre de 1957.

46 España Republicana, Buenos Aires, 15 de junio de 1957, Carta a Su Santidad Pio XII firmada por Xavier Flores. 
documentos podriamos citar difundidos gracias a Gordón Ordás a quien debemos un eterno agradecimiento los miembros de aquellas «nuevas generaciones".

\section{EL GOBIERNO DEL GENERAL EMILIO HERRERA LINARES}

Al cabo de dos meses se resolvió la crisis con el nombramiento de un personaje singular: el general Emilio Herrera Linares, miembro de la Academia de Ciencias de España, ingeniero aeronáutico, gentilhombre de Cámara del rey Alfonso XIII, que siendo monárquico de corazón juró lealtad a la República y la mantuvo hasta su muerte.

Poco puede destacarse de la actuación de este gobierno que duró un par de años hasta el fallecimiento del presidente Martínez Barrio. El general Herrera mantuvo en su gobierno a los dos firmes puntales de siempre: Fernando Valera, ministro de Estado y Relaciones Internacionales, y Julio Just Jimeno, vicepresidente y ministro de Emigración e Interior. Se sumaron dos nuevos desconocidos: Antonio Alonso Baños, recién llegado de España, ministro de Justicia, y Mariano García, ministro de Información y Propaganda. Continuaron en Washington, Londres y Roma los anteriores ministros delegados, y se amplió el número de éstos con Vicente Álvárez Buylla en Caracas, Jesús Vázquez Gayoso en La Habana y Federico Escofet en Bruselas.

En su declaración ministerial del 1 de julio de 1960, el general Herrera se mantuvo en las mismas pautas trazadas por Gordón Ordás. Mantener la presencia del gobierno en París, cuyos medios económicos eran cada vez más precarios, y reiterar el mensaje de la liberación de España, eran dos imperativos ineludibles.

Un acontecimiento destacable -cabe decir que el único- fue la firma, el 10 de febrero de 1961, de un Acuerdo Lusoespañol con el general Humberto Delgado, general de las Fuerzas Aéreas portuguesas, ex-candidato a la presidencia de la República y jefe del Movimiento Nacional Independiente representativo de la oposición democrática portuguesa.

Este acuerdo que venia gestándose desde la época de Álvaro de Albornoz y de Gordón Ordás se concretó a partir del momento en que el general Delgado se exilio en Brasil. El texto íntegro del acuerdo, publicado por José María del Valle, afirmaba el compromiso de que el primer gobierno libertador en uno de los dos países, prestaría su ayuda plena al 
movimiento democrático del país vecino, dando «la mayor protección posible a la parte firmante del presente acuerdo que aún no haya conseguido liberarse de la respectiva dictadura 47 », promesa ésta que no llegó a cumplirse ni con la famosa revolución de los claveles en Portugal, desencadenada en abril de 1974.

Pocos meses después, el 24 de junio de 1961, salió a la luz el pacto de la Unión de Fuerzas Democráticas que se había constituido paralelamente a la creación de Acción Republicana Democrática Española (ARDE), fusión en el exilio de la Unión Republicana de Martínez Barrio e Izquierda Republicana de Azaña.

Este nuevo pacto, cuyo antecedente es el de 1957 sobre las famosas tres hipótesis, y que a la vez podemos considerar como antecedente del pacto de Munich de 1962, tuvo una significación importante por cuanto era la primera vez que se sumaba la Izquierda Demócrata Cristiana (IDC) del interior a una posición colectiva del exilio. Además de la IDC, lo firmaron el PSOE, PNV, UGT, Acción Nacionalista Vasca, Solidaridad de Trabajadores Vascos y ARDE.

De nuevo se reiteró la petición de que al desaparecer el régimen franquista se establecerá un gobierno provisional sin signo institucional definido y se celebrarán elecciones para que los españoles opten por el régimen de su preferencia. El final terminaba con una salvedad significativa que cobraría sentido en el momento de la Transición: «Si pese a lo acordado, se produjera una situación de hecho que no correspondiera a la prevista en este documento, los firmantes se reservan el derecho de adaptar su actitud, llegado el caso, a la significación y conducta de la situación que hubiese sido establecida», Así lo hicieron en 1975, pero ésta ya es otra historia.

El fallecimiento del presidente Martínez Barrio el 1 de enero de 1962 motivó la dimisión de oficio del gobierno Herrera, concretada el 28 de febrero de 1962, además de abrir una crisis grave por el vacío constitucional que se producía. Afortunadamente, la Constitución de la República había previsto la sucesión escalonada en caso de que quedara vacante la Presidencia. En virtud de lo dispuesto en su artículo 74, había sido elegido en México en 1945 Diego Martínez Barrio presidente interino de la República. Al fallecer éste le tocaba el turno al primer vicepresidente de las Cortes, el socialista Luis Jiménez de Asúa, quien, después de consultar a su partido, aceptó asumir la presidencia manteniendo al pro-

47 J. M. del Valle, op. cit., págs. 338-340. 
pio tiempo la primera vicepresidencia de las Cortes y en funciones la presidencia de las mismas. Esta anómala acumulación de responsabilidades - que fue muy criticada por varios grupos políticos- obedecía de hecho a evitar que, estando vacantes la segunda y la tercera vicepresidencia, ocupara la presidencia Dolores Ibarruri, cuarta vicepresidenta. Se temia que la irrupción del Partido Comunista en tal alta posición mermara y perjudicara internacionalmente al gobierno republicano.

\section{EL GOBIERNO SÁNCHEZ ALBORNOZ}

Don Claudio Sánchez Albornoz intentó formar un gobierno ampliamente representativo, con un Consejo de Ministros sin cartera compuesto de personalidades eminentes del exilio -Pablo Casals, Bosch Gimpera, Picasso, etc.-, pero fracasó en sus gestiones y tuvo que contentarse con un gobierno de corte tradicional 48 con Fernando Valera (Estado), Maldonado (Justicia e Información), Just (Emigración e Interior), Gordón Ordás (que renunció), Manuei Lamana (subsecretario de la Presidencia) y Alonso Baño (subsecretario de Emigración e Interior). El gobierno suprimió los cargos de ministros delegados en el extranjero sustituyéndolos por delegados diplomáticos oficiosos en los mismos sitios, pero ya con posibilidades prácticamente nulas de acción.

La ausencia casi permanente de Jiménez de Asúa y Sánchez Albornoz en Buenos Aires, donde los dos eran catedráticos, no contribuyó apenas a desarrollar las actividades del gobierno en París, mantenidas fundamentalmente por Valera, Maidonado y Just.

Mensajes y declaraciones, llamamientos a la unidad, aliento a los movimientos estudiantiles no faltaron, llenos de esperanza en la caída del franquismo. Sólo un acontecimiento importante lo hizo tambalear, aunque, ayudado por las grandes potencias inmersas en la guerra fría, se sostendría trece años más: la reunión de Munich en junio de 1962 con motivo del Congreso del Movimiento Europeo.

A este llamado «contubernio» por la prensa y el gobierno franquista acudieron 118 españoles (unos 80 del interior y los demás de partidos y

48 Véase Alicia ALTED VIGIL, El exilio político republicano y el régimen franquista en los años 1950 a 1962. Trabajo presentado en el Symposium sobre "Spain Civil War, Franco, and the Persistence of the Liberal Political Tradition", Universidad de California, San Diego, marzo de 1987. Publicado en: Melanges de la Casa de Velázquez, t. XXVII, 3, 1991, págs. 85-114. 
grupos políticos del exilio). La cuestión de la sucesión de Franco fue el punto clave de esta reunión que discutimos en dos comisiones: una del exilio, presidida por Salvador de Madariaga, y otra del interior por José María Gil Robles. En el proyecto de resolución presentado por el exilio se sostenía la tesis tradicional de «elecciones libres, en condiciones tales que aseguren la libre expresión del pueblo y la autodeterminación, o sea, la libre elección de régimen, de gobierno y de las estructuras que hayan de regular en el porvenir la convivencia de los ciudadanos en el Estado futuro."

Esta propuesta era inaceptable para los monárquicos constitucionales y otras fuerzas accidentalistas, opuestos a todo plebiscito y partidarios de la monarquía previa. En su proyecto proponían «la organización a intervalos razonables de elecciones libres con escrutinio secreto en condiciones tales que aseguren la libre expresión de la opinión del pueblo en cuanto a la elección del cuerpo legislativo." Así se obviaba el problema del régimen futuro y quedaba descartada la idea del gobierno sin signo institucional preconizada por el exilio.

Ante la imposibilidad de un acuerdo mutuo se formó una comisión mixta presidida por Salvador de Madariaga con representantes de la Comisión A -Gil Robles, Jesús Prados Arrarte, Xavier Flores y Joaquín Satrústegui-y de la Comisión B -Rodolfo Llopis, Fernando Valera, Xavier de Landaburu y Carmelo Cembrero- con la asistencia de Robert van Schendel, secretario general del Movimiento Europeo, y Enrique Gironella, secretario de su Consejo Español.

En esta reunión volvimos a exponer nuestras posiciones respectivas y, para no acabar en una ruptura, optamos por dejar de lado la cuestión del régimen futuro y aceptamos la fórmula de compromiso ideada por Madariaga, que se limitaba a pedir «la instauración de instituciones auténticamente representativas que garanticen que el gobierno se basa en el consentimiento de los gobernados". Asi quedaba salvado el honor de todos.

Un dato significativo y de dolorosa actualidad -no olvidemos que el PNV estaba representado por Landaburu- era «el compromiso de renunciar a toda violencia activa o pasiva, antes, durante y después del proceso evolutivo que cierra el texto de esta resolución que fue aplaudida unánimemente por el Congreso del Movimiento Europeo el 8 de junio de 196249.

49 Véase para más detalles, J. M. DEL VALLE, op. cit. págs. 346-351, Joaquín Sataústegul (ed), Cuando la transición se hizo posible, Madrid, Tecnos, 1993, y Xavier FLores, El Contubernio de Munich, Ibérica, Nueva York, julio-agosto de 1962. 
Otro hecho significativo, recogido por Joaquín Satrústegui, es la declaración que le hizo Rodolfo Llopis, que preveía el desarrollo futuro de los acontecimientos. A título reservado le dijo: «Quiero que usted sepa confidencialmente, y sobre todo lo haga saber al Conde de Barcelona, que nosotros tenemos un compromiso con la República y no lo vamos a abandonar. Vamos a defender la fórmula republicana hasta el final. Ahora bien, quiero que el Conde de Barcelona sepa que si la Corona, de hecho, facilita el tránsito pacífico a la democracia, el PSOE a partir de ese momento respaldará la Corona".

Además del conocido escándalo nacional que organizó Franco, deteniendo, deportando y exiliando a un grupo de participantes, con el elogio unánime de la prensa nacional, la reunión de Munich suscitó tres reacciones importantes.

La primera, del 15 de junio, destacando la trascendencia del acuerdo fue la del presidente Claudio Sánchez Albornoz que, en nombre del gobierno republicano, "acoge con emoción los acuerdos elaborados de manera unánime por los delegados españoles del interior de España y del exilio» y acaba afirmando que "el gobierno de la República española confía en que Europa y América sabrán apreciar en todo su valor la oportunidad que la historia les ofrece de este nuevo Munich, el Munich de la dignidad, que les permite lavar el baldón de ignominia del Munich del deshonor que, en 1938, preparó el desencadenamiento de la segunda guerra mundial 50 .

La segunda reacción, totalmente negativa, fue la del ex-jefe del gobierno Félix Gordón Ordás, dimitido en 1960, que nos aclara que estando él a la cabeza del gobierno no hubiera tolerado la participación de los republicanos, «hasta tal extremo (...) -dice Gordón Ordás- que si en tales momentos hubiera seguido ocupando yo la suprema autoridad gubernativa, habria exigido la previa dimisión de sus cargos a los miembros del gabinete ministerial que estuvieran dispuestos a participar en conversaciones de política nacional con altos renegados de la República y con destacadísimos consejeros de Don Juan 51."

Es evidente que si un efecto positivo tuvo la dimisión de Gordón Ordás fue el de abrir el camino a la reunión de Munich. Con la oposición abierta dei gobierno republicano hubiera sido difícil que los partidos políticos -so-

50 Véase el texto completo en SATRÚstegul, op. cit., págs. 227-228, y del Valle, op. cit., pág. 351.

51 Gordón ORdAs, op. cit., pág. 1.225 IV (II), Carta a Xavier A. Flores del 24 de junio de 1962. 
bre todo ARDE y el PSOE- hubieran acudido a la convocatoria del Movimiento Europeo.

La tercera discrepancia nos llegó sorprendentemente del Consejo Privado de don Juan de Borbón. José María Pemán, presidente del Consejo, y García Valdecasas, secretario, aprovechando que don Juan acababa de regresar de Atenas en su Yate El Saltillo, van a visitarlo y redactan el 15 de junio una nota con unas manifestaciones hechas, según ellos, por el Pretendiente: «El Conde de Barcelona - dice la nota-nada sabía de las reuniones de Munich hasta que, después de ocurridas, escuchó en alta mar las primeras noticias a través de la radio. Nadie, naturalmente, ha llevado a tales reuniones ninguna representación de su Persona ni de sus ideas. Si alguno de los asistentes formaba parte de su Consejo, ha quedado con este acto fuera de él."

Con este texto, que Luis María Ansón califica de indigno 52, quedaba defenestrado Gil Robles. Cabe preguntar cuáles eran, entonces, las ideas de don Juan frente a quien le habia servido lealmente durante tantos años. Lo cierto es que a Franco, como lo demuestra su política en los largos años siguientes, las ideas de don Juan le traían sin cuidado.

Pasaron los años y después de este aldabonazo que fue la reunión de Munich para la conciencia europea, continuó Sánchez Albornoz lanzando mensajes y llamamientos en pro de un frente único sin exclusiones, que fracasaron todos. Por su lado, insensible a toda clase de peticiones, aunque se tratara del Papa, Franco prosiguió su política de encarcelamientos y ejecuciones -recuérdese la de Julián Grimau en 1963- hasta poco antes de su muerte.

\section{EL GOBIERNO VALERA}

El fallecimiento de Luis Jiménez de Asúa el 16 de noviembre de 1970 , dio paso a José Maldonado a la presidencia de la República en virtud de lo dispuesto en el artículo 74 de la Constitución de 1931. El gobierno dimisionario de oficio siguió en funciones hasta el 28 de febrero de 1971 en que Sánchez Albornoz presentó su dimisión a Maldonado, quien le reiteró en vano su confianza. La imposibilidad de formar un gobierno más amplio, intento en el que ya había tracasado Sánchez Albornoz, abrió paso al último gobierno presidido por Fernando Valera Aparicio. Con el apoyo de Julio Just, su brazo derecho, Valera organizó como pudo un nuevo mi-

52 Luis María Ansón, op. cit., pág. 339. 
nisterio, manteniendo a Antonio Alonso Baño en Justicia, nombrando ministro de Economía a Macrino Suárez, de ARDE, y dos ministros delegados en América central y del sur, Francisco Giral y Manuel de Rivacoba respectivamente, los dos de ARDE.

Lo único que podía hacerse ya, a esas alturas del año 1971, era mantener los principios de las Instituciones en el exilio frente a la Ley de Sucesión de Franco que se auguraba funesta para la democracia. «La legitimidad - decía el gobierno en su declaración ministerial del 14 de abril de 1971-es un derecho exclusivo e intransferible del pueblo, y mientras el pueblo español no haya podido manifestar su actual voluntad política en una auténtica consulta electoral libre, nosotros seguiremos proclamando que el único régimen legítimo de España es el que se funda en la Constitución republicana de 1931 y en los Estatutos de Autonomía de ella derivados ${ }^{53}$."

La Junta permanente de Estado, compuesta por los presidentes de la República, del gobierno y de las Cortes, además de los expresidentes de gobierno, y de los presidentes de la Generalidad de Cataluña y del gobierno Vasco, se sumó a esta declaración subrayando, el 31 de mayo de 1971 , el supremo interés nacional de mantener el funcionamiento de las Instituciones republicanas, representativas de la última expresión de la voluntad popular y la necesidad de elecciones sinceras como único procedimiento legal para modificar la Constitución de 1931.

La época franquista se acercaba con un final imprevisto. La Unión de Fuerzas Democráticas intentó, en vano, con personalidades del interior corno Gil Robles, Ridruejo, Álvarez Miranda y otros, que se constituyera un amplio frente nacional y una ampliación del gobierno en el exilio, contando con miembros del interior. Las circunstancias en España no permitieron llegar a un acuerdo. Por su parte, el Consejo Federal Español del Movimiento Europeo lanzó, el 6 de octubre de 1973, un llamamiento a la unión de todas las fuerzas políticas del interior en pro de una alternativa democrática y la eliminación del sistema totalitario. Aunque se reestructuró el Consejo con Manuel de Irujo elegido presidente, la desconexión entre el interior y el exterior, que criticamos muchas veces, impidió que se plasmara el proyecto ${ }^{54}$.

53 J. M. Del VALLE, op. cit., pág. 359.

54 Sobre la falta de un frente común, las dificultades y la desconexión entre el interior y el exterior, así como las perspectivas de la oposición a lo largo de los años, véase Horizonte Español, París, Ruedo Ibérico, 1966, con las críticas de Xavier FloRES, El exilio y España, Jorge SEmprún, La oposición polltica en España, y Fernando CLAUdin, Dos concepciones de la "via española al socialismo». 
Al año siguiente, el 9 de febrero de 1974, Franco, ingresado en el hospital y gravemente enfermo, tuvo que dejar momentáneamente la jefatura del Estado al príncipe Juan Carlos. El 20 de julio, el gobierno en el exilio publicó una declaración sobre el fin de la era franquista, reiterando sus principios, y lanzó la siguiente profecía: «Para transformar el régimen en una verdadera democracia, sería menester que el príncipe quebrantara su juramento de lealtad al Movimiento, como ha quebrantado la lealtad debida a su padre y a su dinastía. No lo hará; no podrá hacerlo; no le consentirían que lo hiciera 55 .» Como sabemos, las cosas no sucedieron así, aunque algunos lo intentaron. La Historia suele vengarse de los profetas.

A la vista de los acontecimientos, el gobierno republicano continuó imperturbable su tarea a lo largo del año 1975. Franco aprovechó los meses que le quedaban de vida para aprobar una durísima ley antiterrorista en agosto, y firmar cinco penas de muerte dos meses antes que la suya, pese a las protestas internacionales y a las peticiones de clemencia del Papa Pablo VI y de don Juan de Borbón.

La muerte de Franco el 20 de noviembre de 1975 introdujo un compás de espera. Nadie podía afirmar que la coronación del príncipe Juan Carlos de Borbón era una garantía de auténtica democratización del régimen. Arias Navarro, partidario de la continuidad del franquismo se mantuvo en la presidencia del gobierno hasta marzo de 1976. A partir de entonces se aceleró el proceso: la designación de Torcuato Fernández Miranda como presidente de las Cortes alteró los proyectos del bunker franquista. Harto sabido es que Fernández Miranda diseñó para el Rey el cambio “de la ley a la ley» y le sugirió el nombre de Adolfo Suárez como sucesor de Arias. La aprobación de la Ley para la Reforma Política el 18 de noviembre de 1976 y su ratificación por referéndum nacional abrió la puerta a la democracia, pero aún faltaba la celebración de elecciones para asentar el proceso que culminaria con la Constitución de 1978.

La alta participación popular en las elecciones del 15 de junio de 1977 determinaron el final de la misión histórica del gobierno republicano en el exilio, cuyo reconocimiento diplomático de México y Yugoslavia ya se había cancelado. El 21 de junio, José Maldonado, presidente de la República, y Fernando Valera, presidente del gobierno, anunciaron el fin de las Instituciones en el exilio ante la nueva realidad derivada de las eleccio-

55 Cf. J. M. oel Valle, op. cit., pág. 363. 
nes, en una declaración que aceptaba el veredicto popular a pesar de que algunos partidos republicanos -entre ellos ARDE e Izquierda Republicana- no habían sido todavía legalizados:

"(...) la numerosa participación electoral, claro exponente del elevado civismo de nuestros compatriotas -que es además un categórico mentís para quienes los tuvieron sojuzgados alegando la inexistencia de ese sentimiento- $y$ unido a aquélla el general consenso con el que se acepta en el país el resultado de la confrontación, nos mueven, a pesar de sus anomalías, a aceptar ese resultado.

Las Instituciones de la República en el exilio ponen así término a la misión histórica que se habían impuesto. Y quienes las han mantenido hasta hoy, se sienten satisfechos porque tienen la convicción de haber cumplido con su deber."

Un mes antes, el 14 de mayo de 1977, don Juan de Borbón, superando las muchas dificultades que le oponían los que se agarraban a la legalidad vigente -la monarquía como «instauración» y no como "restauración»- abdicaba en el palacio de la Zarzuela, por no permitírsele hacerlo en el Palacio Real, la Corona en su hijo Juan Carlos, Rey de hecho desde la muerte de Franco.

Podemos decir que, en aras de la paz, perdimos todos: los partidarios de un plebiscito como lo había imaginado Prieto en sus negociaciones con Gil Robles, los defensores de un gobierno sin signo institucional, y también los monárquicos fieles a don Juan de Borbón -Juan III para ellos- que vieron como al final era definitivamente descartado del Poder. Perdimos todos, es cierto, incluso Franco que soñó con la continuidad del Movimiento, pero al final valió la pena esta larga batalla de la oposición al régimen, que lo mantuvo aislado de las instituciones europeas y de la opinión pública democrática. Sin ella todo hubiera sido más difícil en la transición a la democracia y la devolución al pueblo de sus derechos inalienables. 